\title{
The chemistry and structure of redledgeite
}

\author{
B. M. Gatehouse, ${ }^{1}$ G. C. Jones, ${ }^{3}$ A. Pring ${ }^{2}$ And R. F. Symes ${ }^{3}$
}

${ }^{1}$ Department of Chemistry, Monash University, Clayton, Vic. 3168, Australia. ${ }^{2}$ South Australian Museum, North Terrace, Adelaide, SA 5000, Australia. ${ }^{3}$ Department of Mineralogy, British Museum (Natural History), Cromwell Road, London, SW7 5BD, England.

ABSTRACT. Two distinct habits of redledgeite are described: small black bipyramidal crystals and yellowgreen fibres. The mineral is a $\mathrm{Ba}-\mathrm{Cr}-\mathrm{Ti}$ oxide rather than a $\mathrm{Mg}-\mathrm{Cr}-\mathrm{Ti}$ oxide as previously supposed. Electron microprobe analysis gave $\mathrm{Ba}_{1.10}\left(\mathrm{Cr}_{1.82} \mathrm{Ti}_{5.95}\right.$ $\left.\mathrm{Fe}_{0.10} \mathrm{~V}_{0.08}\right)_{\Sigma 7.95} \mathrm{O}_{16}$ and $\mathrm{Ba}_{1.27}\left(\mathrm{Cr}_{2.48} \mathrm{Ti}_{5.49} \mathrm{Fe}_{0.02}\right)_{\Sigma 7.99}$ $\mathrm{O}_{16}$ for the black and yellow-green forms respectively. The mineral is a monoclinic hollandite-type phase, space group $I 2 / m$, with $a=10.129(2) ; b=2.95(1) ; c=10.135(2)$ $\AA ; \beta=90.05(11)^{\circ}$ and $\mathrm{Z}=1$; calculated density for the black form is $4.413 \mathrm{~g} \mathrm{~cm}^{-3}$. The crystal structure was refined to $R 6.3 \%, R_{w} 7.4 \%$ using 1017 reflections with $F>3 \sigma(F)$ from a set of 1062 unique reflections. Electron diffraction studies revealed weak superlattice reflections, with a period of $2.24 b$ due to tunnel cation ordering.

KEYWORDS: redledgeite, crystal chemistry, hollanditetype structure, Red Ledge gold mine, California.

THE rarest and least well characterized of the hollandite-type minerals is redledgeite. Known only from the Red Ledge gold mine, Washington district, Nevada County, California, USA, the mineral is found in close association with kämmererite, $(\mathrm{Mg}, \mathrm{Cr})_{6}\left(\mathrm{AlSi}_{3}\right) \mathrm{O}_{10}(\mathrm{OH})_{10}$ (a chromium chlinochlore) and chromite $(\mathrm{Mg}, \mathrm{Fe}) \mathrm{Cr}_{2} \mathrm{O}_{4}$. Redledgeite was originally described as 'chromrutile' by Gordon and Shannon (1928). Their analysis gave

$$
\mathrm{Ca}_{0.7} \mathrm{Mg}_{7.1} \mathrm{Cr}_{11.3} \mathrm{Fe}_{0.5} \mathrm{Al}_{0.6} \mathrm{Ti}_{45} \mathrm{Si}_{4.7} \mathrm{H}_{8.7} \mathrm{O}_{130} \text {. }
$$

Strunz $(1961,1963)$ established that the mineral was structurally related to hollandite rather than rutile, and the mineral was renamed after the type locality. Strunz found the mineral to be tetragonal, space group $I 4_{1} / a$, and noted a strong hollandite-like subcell, $a=10.10$ and $c=2.92 \AA$. Evidence of a doubling of both the tetragonal $a$ and $c$ repeats was found, and the full cell was determined as $a_{0}=20.32, c_{0}=5.84 \AA$ (Strunz, 1961). He determined the cell contents, based on the original analysis (Gordon and Shannon, 1928), as $\mathrm{MgTi}_{6} \mathrm{Cr}_{1.5} \mathrm{Si}_{0.5} \mathrm{O}_{16}$ and assigned $\mathrm{Mg}$ to the tunnel sites.

There are two chemically distinct groups of hollandite-type minerals: the manganese oxide hollandites, of which cryptomelane, $\mathrm{KMn}_{8} \mathrm{O}_{16}$, and hollandite, $\mathrm{BaMn}_{8} \mathrm{O}_{16}$, are the most common; and the titanium-oxide-based hollandites of which redledgeite is an example. Both groups of minerals share the same distinctive tunnel structure which was originally determined by Byström and Byström (1950) for the mineral hollandite. The structure, as shown in fig. 1, consists of a framework of octahedrally coordinated metal ions. The octahedra are linked by edge-sharing to form double columns parallel to the tunnel axis. The double strings in turn share corners to form a threedimensional framework containing square tunnels. In the closely related hollandite-type mineral, priderite $(\mathrm{K}, \mathrm{Ba})(\mathrm{Fe}, \mathrm{Ti})_{8} \mathrm{O}_{16}$, the large cations, $\mathrm{Ba}$ and $\mathrm{K}$, occupy the tunnel sites (Post et al., 1982, and

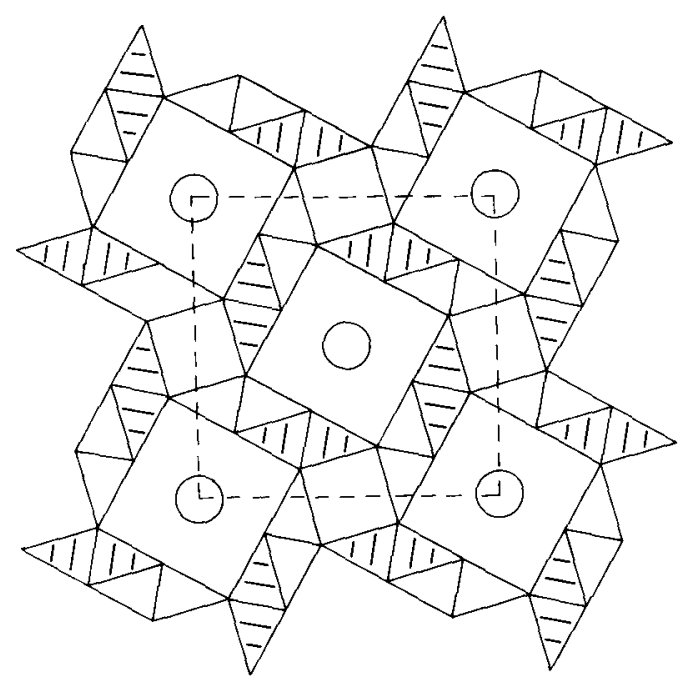

FIG. 1. The idealized tetragonal hollandite structure projected along the tunnel axis [001]. Pairs of edgesharing octahedra form columns parallel to [001] which in turn share corners to form square tunnels which run through the structure. The larger cations ( $\mathrm{Ba}$ in the case of redledgeite) shown as circles occupy eight coordinated sites within the tunnels. 
Sinclair and McLaughlin, 1982). Since Ba and K are much larger than $\mathrm{Mg}$ it was considered unlikely that the structural formula, as proposed by Strunz, could be correct. A re-examination of redledgeite, combining new chemical data from electron microprobe analysis and a structure refinement by singlecrystal X-ray diffraction methods, was therefore undertaken.

\section{DESCRIPTION}

Redledgeite occurs at the Red Ledge mine in two forms. The mineral was originally found as brilliant black bipyramidal crystals, up to $2 \mathrm{~mm}$ in length, on a slightly weathered chromite matrix. Redledgeite also occurs in a dark yellow-green fibrous form which appears not to have been described. A scanning electron microscopic study of the fibrous form revealed tiny prismatic crystals of redledgeite approximately 10 to $15 \mu \mathrm{m}$ in length and less than 1 $\mu \mathrm{m}$ in diameter (fig. 2), although larger fibres, up to several millimetres, have been found. Both forms

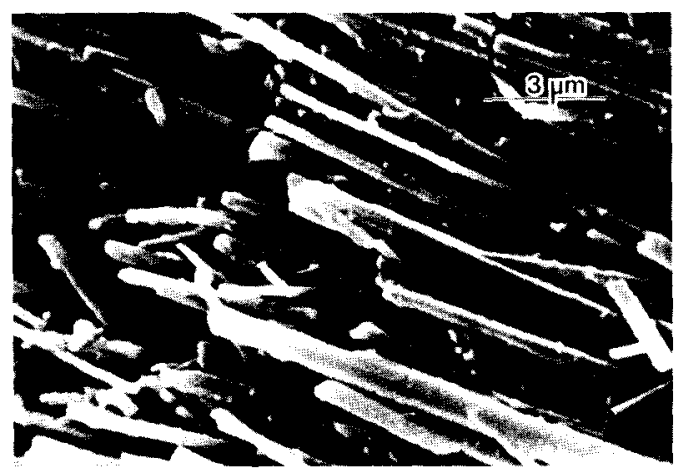

FIG. 2. Scanning electron micrograph of fibrous redledgeite crystals. Individual crystals are approximately 1 $\mu \mathrm{m}$ in diameter and $10-15 \mu \mathrm{m}$ in length.

occur in association with kämmererite and a chromite matrix. The striking difference in colour between the two forms can be attributed to differences in crystal size and chromium and iron contents as thin fracture fragments of the larger black crystals show dark green edges, and the fibres have a higher $\mathrm{Cr}$ and lower $\mathrm{Fe}$ content. The chemical data presented in the following section show that the two forms are otherwise chemically very similar. Measurement on the black crystals gave a Mohs hardness of 6.5 ; it was not possible to determine the hardness of the fibrous crystals.

\section{CHEMICAL ANALYSIS}

One small crystal fragment (maximum dimension $300 \mu \mathrm{m}$ ) of type redledgeite (USNM 95846) was available to us for chemical study, the $\mathrm{X}$-ray diffraction pattern of which was found to be identical to that of black bipyramidal crystals from the redledgeite specimen BM 1928, 336. A polished mount of the type fragment would only take a poor polish but electron microprobe analyses obtained on this were within the elemental range for BM 1928,336 shown in Table I. Several $30 \mu \mathrm{m}$ inclusions of kämmererite were found in this type redledgeite fragment. In order to obtain large areas of well-polished crystal section for analysis, several bipyramidal crystals were selected from BM 1928, 336, mounted, polished and analysed. These crystals were found to be homogeneous and free from inclusions.

Preliminary energy dispersive $\mathrm{X}$-ray analysis of the dark yellow-green fibrous form of redledgeite (BM 1973, 575) revealed that $\mathrm{Ti}, \mathrm{Cr}$, and $\mathrm{Ba}$ were the main chemical constituents, with $\mathrm{Mg}$ absent. Subsequent electron microprobe analysis of specimens of both forms confirmed that redledgeite

\begin{tabular}{|c|c|}
\hline $\begin{array}{l}{ }^{1} \text { Green, f1brous } \\
\text { (BM } 1973,575)\end{array}$ & $\begin{array}{l}2 \text { Black, blpyramidal } \\
\text { crystals (BMI 1928,336) }\end{array}$ \\
\hline $\begin{array}{l}53.0(52.2-53.4) \\
+(54.2)\end{array}$ & $58.6(57.7-59.9)$ \\
\hline $\begin{aligned} 22.8(22.0-23.5) \\
t(21.0)\end{aligned}$ & 17.0 \\
\hline 0.2 & $1.0(0.7-1.4)$ \\
\hline not detected & $\neq 0.7$ \\
\hline $\begin{aligned} & 23.6(22.6-24.7) \\
+ & (20.4)\end{aligned}$ & $20.8(19.2-23.1)$ \\
\hline 89.6 & 98,1 \\
\hline
\end{tabular}

\begin{tabular}{|c|c|c|c|c|c|}
\hline \multicolumn{6}{|c|}{ Cell contents per 16 oxygens } \\
\hline $\mathrm{T} 1$ & 5.49 & & $T 1$ & 5.95 & \\
\hline$C_{r}$ & 2.48 & & Cr & 1.82 & \\
\hline $\mathrm{Fe}$ & 0.02 & & Fe & 0.10 & \\
\hline$v$ & - & & $v$ & 0.08 & \\
\hline Ba & 1.27 & & $\mathrm{Ba}$ & 1.10 & \\
\hline
\end{tabular}

* Total iron determined as $\mathrm{Fe}_{2} \mathrm{C}_{3}$

1) Average of 4 energy d1spersive analyses, + (F1gures $1 \mathrm{n}$ brackets - previous analysis on other fibrous areas).

2) Average of 21 wavelength dispersive an alyses. $₹$ Energy dispersive velue (2 goglyses).

Material was prepared as pol1sted erain mounto. The majority of analyses were carrled out uaing a Cambridge Instruments Microscan 9 wavelength dispersive ingtrument and corrected using a standard ZaF program. Analyals conditions wore $20 \mathrm{kV}\left(2.5 \times 10^{-\bullet} \mathrm{A}\right)$ and standarcs used were baryte, bartum sluoride, pure $\mathrm{Cr}_{r}$, pure $\mathrm{Fe}$, and synthetic rutile. Further analyas were run on a Cambridge Instrurents Geoscan-Link Systems EDS instrurent at $15 \mathrm{kV}\left(0.5 \times 10^{-8} \mathrm{~A}\right)$.

Anelygt G. C. Jones. 
is essentially a barium chromium titanate (see Table I). The microprobe analyses gave the formulae $\mathrm{Ba}_{1.27}\left(\mathrm{Cr}_{2.48} \mathrm{Ti}_{5.49} \mathrm{Fe}_{0.02}\right) \mathrm{O}_{16}$ and $\mathrm{Ba}_{1.10}$ $\left(\mathrm{Cr}_{1.82} \mathrm{Fe}_{0.10} \mathrm{Ti}_{5.95} \mathrm{~V}_{0.08}\right) \mathrm{O}_{16}$ for the fibrous and bipyramidal forms respectively. Trace vanadium was detected and measured in the bipyramidal crystals but was not detected in the fibrous material. The analyses are consistent with the constraints imposed by the nature of the hollandite structure; the number of $\mathrm{Cr}$, $\mathrm{Ti}$ and $\mathrm{Fe}$ atoms sum to approximately eight, indicating full occupation of the eight octahedral sites within the standard hollandite-type cell, as confirmed by the structure refinement (see following section).

Since experimental details are not available for the original wet chemical analysis of redledgeite by Shannon (Gordon and Shannon, 1928), it is not possible to determine whether Ba could have been wrongly assigned as $\mathrm{Mg}$ in the original analysis. The presence of $\mathrm{Si}$, however, indicates that kämmererite $(\mathrm{Mg}, \mathrm{Cr})_{6}\left(\mathrm{AlSi}_{3}\right) \mathrm{O}_{10}(\mathrm{OH})_{8}$ was present as an impurity. Si, if present in redledgeite, would have to occupy an octahedral site within the framework. This is most unlikely as six coordinated silicon is known only in minerals formed at very high pressure (e.g. stishovite, the rutile-like polymorph of $\mathrm{SiO}_{2}$ ). Most of the $\mathrm{Mg}$ in the original analysis could therefore be due to the kämmererite impurity.

\section{CR YSTA L LOGRA PHY \\ Electron diffraction}

Electron diffraction studies of redledgeite were undertaken in an attempt to confirm the $2 a \times 2 c$ supercell reported by Strunz (1961). Crystals of both redledgeite forms were examined by electron microscopy using the same experimental procedures as Pring and Jefferson (1983). The basic tetragonal subcell for redledgeite was confirmed by electron diffraction studies but the true symmetry was later shown to be monoclinic (see structure refinement). The monoclinic $y$ axis is parallel with the tunnels, while in tetragonal hollandite the tunnels are parallel with $z$. Fig. 3 shows an electron diffraction pattern of redledgeite (black crystals) with the beam parallel to [111]; the diffuse superlattice reflections at 0.23 reciprocal lattice units from the rows of principal reflections should be noted. These can be interpreted as a superlattice of period $2.24 \times b$ that roughly corresponds to the doubling of the short axis reported by Strunz. No evidence was found of the doubling of the $10 \AA$ axis which was also reported. Twinning on $(110)_{\text {tet }}$ in hollandite-type compounds is quite common [see example in Post et al. (1982) and the resulting

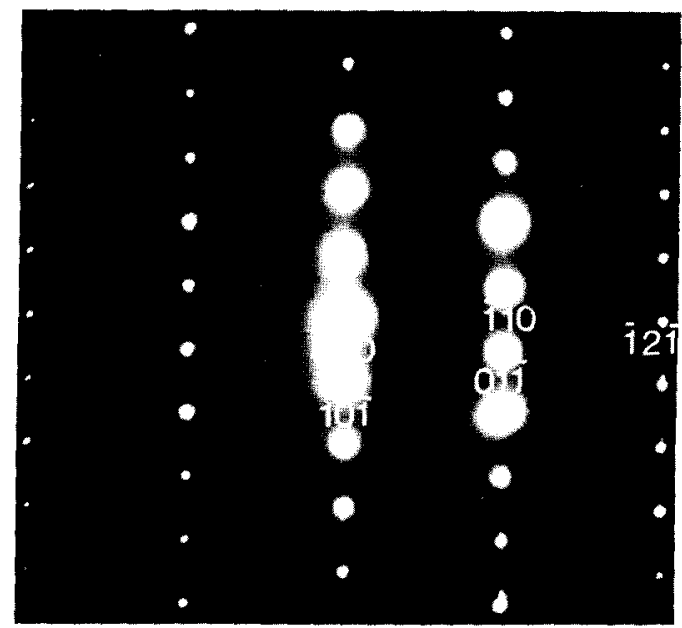

FIG. 3. Electron diffraction pattern produced by a black redledgeite crystal with the beam parallel to [111]. Note the incommensurate superlattice reflections with a period of $4.48 d_{\overline{1} 2 \overline{1}}, 2.24 \times b$ due to the disordered intergrowth of $5 b$ body centred supercells with $b$ supercells in the ratio $1: 1$.

doubling of reflections in the [110] direction could be interpreted as a doubling of $a$, noting that $(h 00)$ with $h \neq 2 n$ reflections are absent in body-centred cells].

The origin of superlattice ordering in hollanditetype compounds has been the subject of considerable research during the last few years. Bursill and Grzinic (1980) showed that incommensurate superlattices in tetragonal hollandites, of the type $\mathrm{Ba}_{x} \mathrm{Al}_{2 x} \mathrm{Ti}_{8-2 x} \mathrm{O}_{16}$ and $\mathrm{Ba}_{x} \mathrm{Ga}_{2 x} \mathrm{Ti}_{8-2 x} \mathrm{O}_{16}$, were due to the disordered intergrowth of $2 c$ supercells with supercells of a large period (i.e. $5 c$ and $6 c$ ). The supercells are formed by ordering of the large $\mathrm{Ba}$ cations in the tunnel sites. Bursill and Grzinic's model for supercell ordering has recently been used to explain superlattice reflections observed in priderite (Pring and Jefferson, 1983), and likewise it can be extended to redledgeite. The observed superlattice corresponds to the disordered intergrowth of $5 b$ supercells with $2 b$ supercells in a ratio of approximately $1: 1$. This implies a tunnel stoichiometry of $1.1 \mathrm{Ba}$ atoms per cell, a value in good agreement with the analytical figure. Tunnel cation ordering is discussed later in connection with results of the structure refinement.

\section{Structure refinement}

Intensity measurement. Specimens of both forms of the mineral were examined. Because crystals of 
the fibrous form were found to be unsuitable for structure determination, a small black crystal fragment was selected for this purpose from the type material (USNM no. 95846). The data crystal, a square based trigonal prism (see below) $(0.175 \mathrm{~mm}$ high by $0.15 \mathrm{~mm}$ on edge) was mounted on a silica-glass capillary and transferred to a Philips PW1100 4-circle automatic diffractometer for intensity measurement. Least squares refinement of $2 \theta$ values obtained for centred high-angle reflections gave the pseudo-tetragonal cell $a=10.129$ (2), $b=2.951(1), c=10.135(2) \AA$, but examination of Friedel sets of reflections indicated the true symmetry to be monoclinic with $\beta=90.05(11)^{\circ}$. The systematic extinctions were found to be consistent with the space group $C 2 / m$, but the non-standard setting $I 2 / m$ was adopted as $\beta$ is then $90.00^{\circ}$ and the structure is easily compared with the tetragonal hollandite phases. Intensity data were collected with graphite monochromated Mo- $K \alpha$ radiation $(\lambda=0.71069 \AA)$. An $\omega-2 \theta$ scan, $2 \theta$ limits $6-60^{\circ}$, was used with a scan speed of $0.04^{\circ} \mathrm{sec}^{-1}$. Two background measurements, each for half the scan time, were made at the scan limits. Intensities were processed in the manner described by Fallon and Gatehouse (1980). A quantity of 1105 reflections were measured and reduced to a set of 1062 unique reflections of which 1017 had $F>3 \sigma(F)$ and were used in the final refinement. An absorption correction based on the crystal faces (101), (10T), $(\overline{2} \overline{1} \overline{2}),(101)$ and $(11 \overline{2})$ was applied; the maximum and minimum transmission factors were 0.4313 and 0.2947 respectively. Scattering factor curves for $\mathrm{Ba}, \mathrm{Cr}, \mathrm{Ti}$, and $\mathrm{O}$ neutral atoms were those of Cromer and Mann (1968). All computing was carried out on the Monash University Burroughs 6700 computer. The major program used was SHELX76 (Sheldrick, 1976).

Structure solution and refinement. The structure was solved by Patterson methods; Ba was assigned to the origin and the two metal ion sites were identified. Subsequent difference Fourier syntheses revealed the positions of the oxygen atoms and an additional tunnel site displaced from the origin along the $y$ axis. The positional and isotropic thermal parameters were refined over three cycles of least-squares refinement. The distribution of the $\mathrm{Ba}$ ions over the two tunnel sites $(0,0,0$ and 0.0 , $0.1405,0.0)$ was refined by fixing, in alternate cycles, first the temperature factors and then the occupancy factors. The distribution of $\mathrm{Cr}$ and $\mathrm{T}$ between the two octahedral metal sites was refined but no preferential substitution of $\mathrm{Ti}$ by $\mathrm{Cr}$ was observed. The oxygen distribution about the two octahedral sites is very similar, further indicating that there is no preferential $\mathrm{Cr}$ ordering into one of the octahedral sites.

After three final cycles of refinement, with anisotropic temperature factors, the refinement converged giving $R=0.063 R_{\mathrm{w}}=0.074$. The final atomic parameters are presented in Table II and selected bond lengths and angles are given in Table III

\section{DISCUSSION}

Redledgeite is the chromium analogue of the minerals priderite- $\mathrm{Ba}, \mathrm{BaFe}_{2} \mathrm{Ti}_{6} \mathrm{O}_{16}$ (Zhuravkeva et al., 1978), and mannardite, $\mathrm{BaV}_{2} \mathrm{Ti}_{6} \mathrm{O}_{16}$ (Scott and Peatfield, 1986). Redledgeite and priderite are closely related crystallographically and have very similar final atomic parameters, bond lengths and angles; however, the slight differences in atomic positions result in redledgeite (monoclinic) possessing lower symmetry than priderite (tetragonal).

Two tunnel sites, both partially occupied, were located in the refinement of redledgeite. The principal site at the origin contains $75 \%$ of the $\mathrm{Ba}$ ions and the remainder resides in a second site at $0.0,0.1405,0.0$. One possible explanation for the

TABLE II. L1st of atomic_parameters including equivelent 1 sotropic

thermal parameters (with e.s.c.'g)

\begin{tabular}{|c|c|c|c|c|c|}
\hline & $x$ & $y$ & $\mathbf{z}$ & Occupancy & $\operatorname{Veq}(\AA)^{2}$ \\
\hline $\mathrm{Ba}(1)$ & 0.0000 & 0.0000 & 0.0000 & 43.9 (3)\% & $0.0200(10)$ \\
\hline $\operatorname{Bn}(2)$ & 0.0000 & $0.1405(30)$ & 0.0000 & $11.1(3) \%$ & $0.0100(30)$ \\
\hline $\mathbf{u}(1)(\mathrm{CrT} 1)$ & $0.1506(1)$ & 0.0000 & $0.664(1)$ & $100 \%$ & $0.0068(3)$ \\
\hline$k(2)(C x T 1)$ & 0.3336 (1) & 0.0000 & $0.1507(1)$ & $100 \%$ & $0.0066(3)$ \\
\hline$O(1)$ & $0.0392(3)$ & 0.0000 & $0.3346(4)$ & $100 \%$ & $0.0062(5)$ \\
\hline$O(2)$ & $0.6657(3)$ & 0.0000 & $0.0399(4)$ & $100 \%$ & $0.0065(5)$ \\
\hline $0(3)$ & $0.2967(3)$ & 0.0000 & $0.3441(4)$ & $100 \%$ & $0.0058(5)$ \\
\hline $0(4)$ & $0.6557(3)$ & 0.0000 & $0.2969(4)$ & $100 \%$ & $0.0056(5)$ \\
\hline
\end{tabular}

Veq $=\left(U_{1}, U_{2}, U_{3},\right)^{1 / 3}$ 
TAEIE III. Se lected bond lengths and angles for redledgeite (w1the.8.d.'s)

\begin{tabular}{|c|c|c|}
\hline $\operatorname{Ba}(1)-0(4)$ & $(\times 4)$ & $2.984(3)$ \\
\hline $\mathrm{Ba}(1)-0(3)$ & $(\times 4)$ & $2.986(3)$ \\
\hline $\mathrm{Ba}(1)-0(2)$ & $(x 4)$ & $3.410(3)$ \\
\hline $\mathrm{Ba}(1)-O(1)$ & $(\times 4)$ & $3.415(4)$ \\
\hline $\mathrm{Ba}(2)-0(4)$ & $(\times 2)$ & $2.802(5)$ \\
\hline $\mathrm{Ba}(2)-0(3)$ & $(\times 2)$ & $2.804(5)$ \\
\hline $\mathrm{Ba}(2)-0(4)$ & (x2) & $3.209(6)$ \\
\hline $\operatorname{Ba}(2)-0(3)$ & $(\times 2)$ & $3.211(6)$ \\
\hline $\mathrm{Ba}(2)-\mathrm{O}(2)$ & $(\times 2)$ & $3.435(4)$ \\
\hline $\mathrm{Ba}(2)-0(1)$ & $(\times 2)$ & $3,440(4)$ \\
\hline$u(1)-O(1)$ & & $1.923(4)$ \\
\hline$M(1)-0(2)$ & $(\times 2)$ & $1.961(2)$ \\
\hline$H(1)-O(4)$ & $(\times 2)$ & $1,982(2)$ \\
\hline$M(1)-O(4)$ & & $1.997(4)$ \\
\hline$H(2)-O(2)$ & & $1.932(4)$ \\
\hline $\mathbb{M}(2)-O(1)$ & $(\times 2)$ & $1.965(2)$ \\
\hline$M(2)-O(3)$ & $(\times 2)$ & $1.980(2)$ \\
\hline$M(2)-O(3)$ & & $1.995(4)$ \\
\hline
\end{tabular}

presence of the second or 'satellite' site is that it represents an artefact associated with the incommensurate superlattice reflections noted in the previous section. However, the position of the site is inconsistent with the observed superlattice period; one would expect an artefact associated with the superlattice to occur at $0.0,0.1100,0.0$. Since the intensities of these reflections were not included in the refinement, it is unlikely that an artefact would appear. It is more probable that the satellite $\mathrm{Ba}$ population is real and associated with cationcation repulsions when adjacent tunnel sites are occupied. The separation of adjacent sites is 2.951 $\AA$, corresponding to the $b$ repeat; this is close to the ionic diameter of $\mathrm{Ba}, 2.84 \AA$, in eight-coordination with oxygen (Shannon and Prewitt, 1969). Strong repulsion between $\mathrm{Ba}$ ions in adjacent sites causes displacement from the origin, thus minimizing these interactions. The predicted intergrowth of $5 b$ and $2 b$ supercells results, on average, in $28.5 \%$ of the $\mathrm{Ba}$ ions occupying adjacent tunnel sites, a value similar to the occupancy of the satellite site (see fig. 4).
Similar satellite tunnel sites have been reported for priderite (Sinclair and McLaughlin, 1982, and Post et al., 1982) and in the synthetic hollandite phase $\mathrm{BaAl}_{2} \mathrm{Ti}_{6} \mathrm{O}_{16}$ (Sinclair et al., 1980). The priderite crystals studied contained both $\mathrm{K}$ and $\mathrm{Ba}$ tunnel cations and it is argued that the satellite site results from the positioning of the smaller $\mathrm{Ba}$ ion close to one end of the site (Sinclair and McLaughlin, 1982, and Post et al., 1982). The assignment of $\mathrm{Ba}$ to this site is, however, somewhat ambiguous because the electron densities of the $\mathrm{Ba}$ and $\mathrm{K}$ fractions are almost equal, both eleven electrons. It is possible that the satellite site in priderite contains mainly $\mathrm{Ba}$ due to the high repulsion between $\mathrm{Ba}$ ions along the tunnel; however, a sizeable contribution from $\mathrm{K}$ ions cannot be ruled out. For the compound $\mathrm{BaAl}_{2}$ $\mathrm{Ti}_{6} \mathrm{O}_{16}$, Sinclair et al. (1980) invoked cation-cation repulsion to explain the presence of satellite tunnel sites. In the extreme case of $\mathrm{Ba}_{1.33} \mathrm{Cr}_{2.66} \mathrm{Sn}_{5.34} \mathrm{O}_{16}$ all the $\mathrm{Ba}$ is located at the displaced site. The

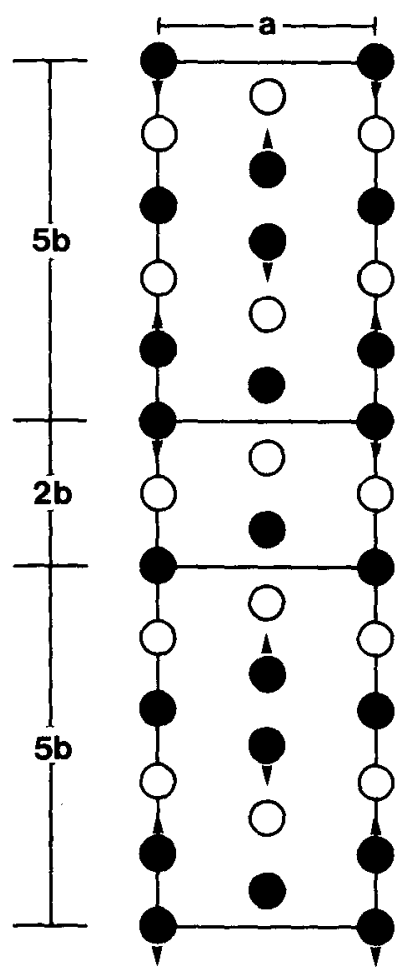

FIG. 4. Schematic diagram of the hollandite structure showing only the sequence of tunnel cation sites in ordered supercells. When adjacent sites are occupied, cation-cation repulsions result in tunnel cation displacement towards the vacant sites (open circles), as indicated by arrow heads. 
stoichiometry of this compound is such that twothirds of the tunnel sites are occupied and thus all Ba cations are paired (Cadée and Verschoor, 1978).

Mannardite, the vanadium analogue of redledgeite, in addition to $\mathrm{Ba}$, contains water within the tunnel sites (Scott and Peatfield, 1986). Lack of material prevented the determination of water in redledgeite. The analytical total for the black form of redledgeite is $1.9 \%$ low (Table I). This shortfall, if assigned to water, corresponds to $0.86 \mathrm{H}_{2} \mathrm{O}$ per cell. However, water was not detected during the structure refinement but the possibility that the satellite tunnel site might be due to water was considered. Difference Fourier maps, calculated using only high angle reflections $\left(2 \theta>40^{\circ}\right)$, confirmed the Ba occupancy of the satellite tunnel site. At high angles $[(\sin \theta) / \lambda>0.5]$, the scattering power of oxygen declines markedly while that of $\mathrm{Ba}$ remains high. If water is present in redledgeite, it will almost certainly occupy the vacant tunnel sites centred on the origin (see fig. 4).

The cause of the small monoclinic distortions observed in many hollandites has been the subject of considerable interest. Sinclair et al. (1980) noted a correlation between the size of the octahedrally coordinated cation and the degree of monoclinic distortion; hollandites with larger $M$-type cations tend to be monoclinic. They argued that, as the size of $M$ increases, the distortion of the framework octahedra also increases. Post et al. (1982) point out that the octahedra in all hollandites are distorted due to edge sharing. They propose, instead, that the monoclinic distortion is related to the displacement of cations from the centre of the octahedra. Displacement along the triad rather than the tetrad axes of the octahedra results in a twisting of the framework and a degeneration of the symmetry. To date, however, neither theory explains comprehensively the observed symmetrics for all hollandite-type phases. The monoclinic distortion is often very slight and thus difficult to detect; the cause of the distortion warrants further investigation.

\section{CONCLUSIONS}

Analysis of redledgeite has shown that the mineral is a barium chromium titanate and not a magnesium chromium titanate, as previously supposed. Redledgeite is the chromium analogue of priderite-Ba and mannardite.

Redledgeite has a hollandite-type structure but its symmetry is distorted from tetragonal to monoclinic. Ordering of the $\mathrm{Ba}$ ions in the tunnels leads to incommensurate 'superlattice' reflections. Supercell ordering reduces the electrostatic interactions between tunnel cations, which are also reduced by displacing adjacent tunnel cations away from each other along the tunnels.

Acknowledgements. One of us (A.P.) would like to thank Professor J. M. Thomas and Dr D. A. Jefferson for help and encouragement in the initial stages of this work. Dr J. E. Chisholm is thanked for his very constructive comments; Dr John S. White of the Smithsonian Institution, Washington, for provision of a type crystal, and $\mathrm{Dr}_{\mathrm{r}}$ I. E. Grey of CSIRO Mineral Chemistry, Melbourne, for access to his unpublished studies on the mineral. We acknowledge the financial support of the ARGC, AERE Harwell, SERC and the University of Cambridge.

Note. A full listing of structure factors for the redledgeite refinement can be obtained from the Mineral Library of the British Museum (Natural History), Cromwell Road, London SW7 5BD.

\section{ADDENDUM}

After this paper was accepted for publication Scott and Peatfield (1986) published a paper describing mannardite $\left(\mathrm{BaV}_{2} \mathrm{Ti}_{6} \mathrm{O}_{16}\right)$; they also presented a brief redefinition of redledgeite. Their conclusions on the chemistry of this mineral agree with ours but their description of the crystallography of redledgeite differs from that presented here. Scott and Peatfield found a well ordered $2 c$ supercell for mannardite; Szymanski (1986) refined the $2 c$ superstructure of mannardite in a tetragonal body centred cell $a=14.356, c=5.911 \AA$. Scott and Peatfield found a similar tetragonal cell for redledgeite, i.e. sharp reflections from a dominant $2 c$ supercell.

We have not observed these sharp reflections on diffraction patterns such as fig. 3 which would have shown them had they been present. Our results and those of Scott and Peatfield (1986) show that different crystals can have different superlattice periods, probably related to slight differences in stoichiometry. The superlattice period has been shown to vary with stoichiometry in synthetic hollandites (Bursill and Grzinic, 1980). In this paper we refined the basic hollandite subcell; the superlattice reflections were too diffuse to be included in the refinement.

\section{REFERENCES}

Bursill, L. A., and Grzinic, G. (1980) Acta Crystallogr. B36, 2902.

Byström, A., and Byström, A. M. (1950) Ibid. 3, 146.

Cadée, M. C., and Verschoor, G. C. (1978) Ibid. B34, 3554. Cromer, D. T., and Mann, J. B. (1968) Ibid. A34, 321.

Fallon, G. D., and Gatehouse, B. M. (1980) J. Solid State Chem. 34, 1193.

Gordon, S. G., and Shannon, E. V.(1928) Am. Mineral. 13, 69.

Post, J. E., Von Dreele, R. B., and Buseck, P. R. (1982) Acta Crystallogr. B38, 1056.

Pring, A., and Jefferson, D. J. (1983) Mineral. Mag. 47,65. Scott, J. D., and Peatfield, G. R. (1986) Can. Mineral. 24, 55.

Shannon, R. D., and Prewitt, C. T. (1969) Acta Crystallogr. B25, 925. 
Sheldrick, G. M. (1976) SHELX76. Program for crystal structure determination. Cambridge University, England.

Sinclair, W., and McLaughlin, G. M. (1982) Acta Crystallogr. B38, 245.

Ringwood, A. E. (1980) Ibid. B38, 2913.

Strunz, M. (1961) Neues Jahrb. Mineral. Mh. 107.
(1963) Ibid. 116.

Szymanski, J. T. (1986) Can. Mineral. 24, 67.

Zhuravkeva, L. N., Yarkina, K. V., and Ryabera, E. G. (1978) Dokl. Akad. Nauk SSSR, 239, 435.

[Manuscript received 11 October 1985; revised 25 June 1986] 